\title{
A NEW SPECIES OF LIACARUS FROM A WOOD RAT NEST (ACARINA: CRYPTOSTIGMATA, LIACARIDAE)
}

\author{
Harold G. Higgins ${ }^{1}$ and Tyler A. Woolley ${ }^{2}$
}

A number of different groups of mites are represented in the fauna found in rodent nests. Many of the mites are predaceous forms and the biotic relationships have not been explained fully. Others are parasitic forms that may have temporarily moved off their hosts (Daniel, 1969). Free-living oribatid mites are sometimes found in nests (Woolley and Higgins, 1968), but have been reported infrequently up to now. It is possible that these oribatids are natural inhabitants of the soil adjacent to the nests of the rodents and have migrated in, but they could also have been picked up from the soil and carried from nest to nest in the fur of the animals.

In the spring of 1969 a collection of mites taken from the sleeping nest of the Wood Rat (Neotoma fuscipes) was received from Mr. Tom Ashley of El Cajon, California. Among these was an undescribed species in the genus Liacarus as designated and summarized in the article of Woolley (1968). The new species has the barbed and spindleform sensillus typical of the genus, but specific differences separate it from known species.

\section{Liacarus lectronus, sp. n.}

(Figs. 1-3)

Diagnosis. The new species is most similar to Liacarus robustus Ewing, 1918, but is smaller in size and has a much smaller mucro, wider lamellae, pointed lamellar cusps and much longer interlamellar hairs. The trivial name comes from the Greek lektron implying "bed" and refers to the sleeping nest of the rodent from which it was taken.

Description. Color dark reddish-brown; prodorsum triangular, about a sixth as long as notogaster; rostrum notched, tip rounded; rostral hairs two-thirds as long as lamellar hairs, finely barbed, inserted in raised forward ridge of tutoria; lamellae broad, narrowed anteriorly, with bidentate cusps, medial dens twice as large as lateral dens; lamellar hairs about half as long as interlamellar hairs, inserted in dorsal surface of lamellae just behind anterior notch of lamellar cusp, finely barbed (Fig. 2); translamella with a prominent mucro extending from base of lamellae to level of insertions of lamellar hairs; interlamellar hairs twice as long as lamellar hairs, extended forward from insertions to level of tips of rostral hairs, finely barbed, inserted in medial margins of lamellae near dorsosejugal suture; pseudostigmata covered by clear, narrow shoulder patches of noto-

${ }^{1}$ Granger High School, Salt Lake City, Utah.

'Department of Zoology, Colorado State University, Fort Collins; research supported in part by NIH-NIAID-TG TO1-AI00094-10. 

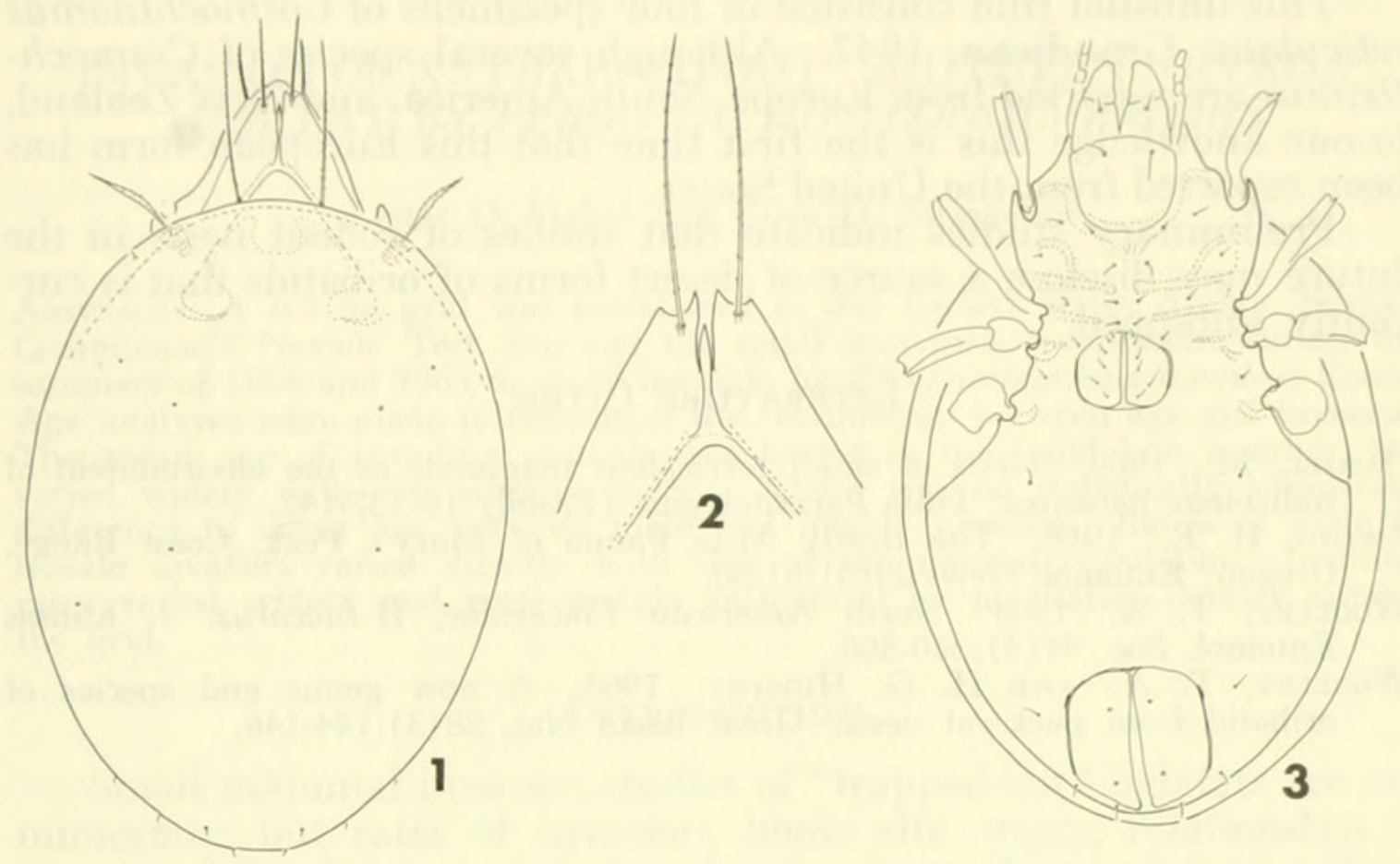

Fig. 1. Liacarus lectronus, from the dorsal aspect, legs omitted.

Fig. 2. L. lectronus, enlarged view of lamellae, mucro and lamellar hairs.

Fig. 3. L. lectronus, from the ventral aspect; legs partially omitted, but showing keeled femora I, II, III.

gaster, spiraled beneath surface; sensillus spindleform, finely barbed; pedotecta I with rounded tip.

Notogaster oval in outline; narrowed, clear shoulder patches extended over sensillus, with two fine, humeral bristles; ten pairs of fine notogastral setae visible in specimens (Fig. 1).

Camerostome oval, infarcapitulum diarthric; rutella, mentum, ventral setae and apodemata as in Fig. 3; genital opening smaller than anal; each genital cover with six setae, g:5 inserted more laterally than other setae on cover; aggenital setae widely separated, insertions closer to genital opening than to anal; anal opening nearly square, each anal cover with two setae inserted nearer medial margin than lateral; fissure iad and adanal setae as in Figure 3, ada: 3 more remote from opening than ada: 2 or ada: 1 . keel.

Legs heterotridactylous; femora I, II, III each with fine pointed

Measurements. The type female measures $702 \mu \mathrm{x} 438 \mu$.

Collection Data. Three specimens, two females and a male, were collected from the sleeping nest of Neotoma fuscipes, 20 March 1968, at Cuyanaca Reservoir, San Diego Co., California, by Tom Ashley. The type will be deposited in the U. S. National Museum. The paratypes will be retained by the authors.

Discussion. In the same collection with L. lectronus, sp. $\mathrm{n}$. from the Neotoma nest was another species that has been recorded from Europe previously, but not from the United States. 
The Great Basin Naturalist H. G. Higgins AND T. A. Woolley Vol. XXIX, No. 3

This unusual find consisted of four specimens of Cosmochthonius reticulatus Grandjean, 1947. Although several species of Cosmochthonius are reported from Europe, South America, and New Zealand, to our knowledge this is the first time that this European form has been reported from the United States.

Preliminary studies indicate that studies of rodent nests in the future may disclose a source of desert forms of oribatids that is currently untapped.

\section{Literature Cited}

DANiel, M. 1969. Nests of small terricolous mammals as the environment of nidicolous parasites. Folia Parasitologica (Praha) 16:137-142.

Ewing, H. E. 1918. The Beetly Mite Fauna of Mary's Peak, Coast Range, Oregon. Entomol. News 29(3):81-90.

Woolley, T. A. 1968. North American Liacaridae, II-Liacarus. J. Kansas Entomol. Soc. $41(3): 350-366$.

Woolley, T. A., and H. G. Higgins. 1968. A new genus and species of oribatid from pack rat nests. Great Basin Nat. 28(3):144-146. 


\section{$2 \mathrm{BHL}$ Biodiversity Heritage Library}

1969. "A new species of Liacarus from a wood rat nest (Acarina:

Cryptostigmata, Liacaridae)." The Great Basin naturalist 29, 140-142. https://doi.org/10.5962/bhl.part.17058.

View This Item Online: $\underline{\text { https://www.biodiversitylibrary.org/item/33897 }}$

DOI: https://doi.org/10.5962/bhl.part.17058

Permalink: https://www.biodiversitylibrary.org/partpdf/17058

\section{Holding Institution}

Harvard University, Museum of Comparative Zoology, Ernst Mayr Library

\section{Sponsored by}

Harvard University, Museum of Comparative Zoology, Ernst Mayr Library

\section{Copyright \& Reuse}

Copyright Status: In copyright. Digitized with the permission of the rights holder.

License: http://creativecommons.org/licenses/by-nc-sa/3.0/

Rights: https://biodiversitylibrary.org/permissions

This document was created from content at the Biodiversity Heritage Library, the world's largest open access digital library for biodiversity literature and archives. Visit BHL at https://www.biodiversitylibrary.org. 